\title{
Insulin Secretion in Response to Glycemic Stimulus: Relation of Delayed Initial Release to Carbohy- drate Intolerance in Mild Diabetes Mellitus*
}

\author{
Holbrooke S. Seltzer, † E. William Allen, Arthur L. Herron, Jr., and \\ MildRed T. BRENNAN \\ (From the Endocrinology Section, Veterans Administration Hospital, and the Department of \\ Internal Medicine, The University of Texas Southwestern Medical School, \\ Dallas, Texas)
}

Summary. Insulin secretory responses to paired intravenous and oral glucose loads were determined in 38 nonobese individuals classified as normal (nondiabetic) subjects, "mild" diabetics (fasting blood glucose below $105 \mathrm{mg}$ per $100 \mathrm{ml}$ ), or "moderate" diabetics (fasting glucose below $192 \mathrm{mg}$ per 100 $\mathrm{ml}$ ). Studies were also performed in 29 obese persons who were similarly grouped. The intravenous load was given to assess the alacrity of hormonal release after glycemic stimulus, and the oral glucose to determine how the speed of initial insulinogenesis modifies the disposition of ingested carbohydrate.

In the nonobese group, normal subjects responded to massive hyperglycemia after rapid injection of glucose with immediate and maximal outpouring of insulin, in contrast to a desultory insulinogenic response in patients with mild diabetes, and no initial response at all in moderate diabetics. During oral glucose tolerance tests, the much faster clearance of blood sugar in nondiabetic subjects was actually associated with lower absolute insulin output than was found in mildly diabetic patients, since the latter exhibited delayed hyperinsulinemia in concert with prolonged hyperglycemia. Moderate diabetics never showed excessive insulin release despite even greater hyperglycemia. An empirical "insulinogenic index," the ratio relating enhancement of circulating insulin to magnitude of corresponding glycemic stimulus, was used to compare the secretory capacities of respective groups. Despite the higher absolute hormonal output after oral glucose in mild diabetics, the index revealed that insulin release in normal subjects was proportionally more than twice as great. This relatively greater normal secretory response declared itself shortly after the administration of glucose by either route, and was maintained throughout both tests.

In the 29 obese individuals, differences among groups were essentially the same as in persons of normal weight. Obese nondiabetics did show much larger absolute insulinogenic responses during both tests than did nonobese controls. Since corresponding glucose tolerance curves were also higher, the mean insulinogenic indexes for obese subjects were not statistically greater. Moreover, when comparable glucose curves of obese and nonobese controls

* Submitted for publication September 13, 1965; accepted November 3, 1966.

This study was supported in part by research grant A-4708 from the National Institutes of Health and by a grant from the Upjohn Co., Kalamazoo, Mich.
This work was presented in part at the Forty-fifth Annual Session of the American College of Physicians, Atlantic City, N. J., on April 10, 1964.

$\dagger$ Address requests for reprints to Dr. Holbrooke S. Seltzer, Veterans Administration Hospital, 4500 S. Lancaster Rd., Dallas, Texas 75216. 
were matched, the apparent hyperinsulinemia associated with obesity was again reduced to insignificance. At the same time, a tendency toward perpetuation of higher insulin levels in overweight normal subjects and mild diabetics, in response to both glucose loads, suggested that obesity per se does induce a state of peripheral insulin resistance.

The data indicate that normal beta cells respond instantly to a glycemic stimulus, whereas diabetic islets react sluggishly, and that proportionally greater insulinogenesis accounts for faster disposal of postprandial hyperglycemia in nondiabetics than in diabetics, in both nonobese and obese individuals. By tracing a rational sequence of events within the beta cell-from normal intact secretory reserve, to its early impairment in mild diabetes, and finally to advanced functional deficiency in moderate diabetics-our findings strengthen the concept that the primary lesion in hereditary diabetes mellitus may well be an intrinsic defect of the beta cell.

\section{Introduction}

That the normal beta cell responds promptly and proportionally to a rising blood glucose concentration was shown by Metz (1) and confirmed by Seltzer (2). Moreover, the interpretation invoked by Seltzer, Fajans, and Conn (3), that the occurrence of symptomatic postprandial hypoglycemia in patients with mild diabetes mellitus might be due to delayed initial release of insulin followed by subsequent excessive hormonal secretion, was suggestively confirmed when Yalow and Berson (4) found subnormal plasma insulin concentrations at 30 minutes during glucose tolerance testing of mild diabetics but supernormal levels at 2 hours. The present study was designed to determine whether this postulated "biochemical inertia" of beta cell response is in fact demonstrable in the earliest stage of clinical diabetes, and, if so, whether it seems causally related to the delayed clearance of postprandial hyperglycemia. We found that both the speed of insulin release and the quantity of insulin secreted per unit of glycemic stimulus are much greater in normal subjects than in the mildest diabetic patients, in both nonobese and obese individuals.

\section{Methods}

Paired intravenous and oral glucose loads were given to 32 subjects with normal glucose tolerance; to $21 \mathrm{pa}$ tients designated as "mild" diabetics, since fasting blood glucose was below $105 \mathrm{mg}$ per $100 \mathrm{ml}$; and to 14 "moderate" diabetics whose fasting blood glucose was between 106 and $192 \mathrm{mg}$ per $100 \mathrm{ml}$. Eleven of the normal subjects were obese (20 to $130 \%$, averaging $60 \%$ above "desirable" 1 body weight), 11 mild diabetics were 18 to $119 \%$ overweight (mean $46 \%$ ), and 7 moderate diabetics were 16 to $73 \%$ overweight (average $39 \%$ ). Within the normal group, 3 nonobese and 2 obese subjects had a positive family history of diabetes. Mean age of normal subjects was 33 years, with a range of 23 to 54 years; average age of mild diabetics was 47 years (24 to 69 years); and mean age of moderate diabetics was 48 years ( 30 to 69 years). All individuals were men except 3 nonobese normal women and 1 nonobese woman with mild diabetes. All diabetic patients had been recently diagnosed, and none had previously been treated.

After standard dietary preparation with monitored intake of $300 \mathrm{~g}$ carbohydrate and 3,000 calories daily for at least 3 days, each patient was given intravenous and oral glucose, in random order and at intervals of a few days. All tests were done with individuals in the recumbent position. For the intravenous test, $0.5 \mathrm{~g}$ of glucose per $\mathrm{kg}$ of actual body weight was injected into an antecubital vein in exactly 5 minutes; for oral testing, a solution containing $1.75 \mathrm{~g}$ of glucose per $\mathrm{kg}$ of desirable body weight was consumed within 5 minutes. Samples were timed from the start of injection or the first swallow of glucose solution, respectively. During the intravenous test antecubital venous blood samples for whole blood glucose and plasma insulin were obtained at $5,10,20,30$, $45,60,90$, and 120 minutes; after the oral glucose load specimens were drawn at $10,20,30,45$, and 60 minutes, then each half hour through the fourth hour. Whole blood glucose was determined in duplicate by the SomogyiNelson method (6), and plasma insulin concentration was determined by a slight modification of the radioimmunoassay of Yalow and Berson (4). Chromatographic separation of bound and free insulin- ${ }^{121} I$ in an air-conditioned

1 "Desirable" body weight was obtained from the Tables of Desirable Weights for Men and Women, Metropolitan Life Insurance Company, Statistical Bureau (5). For a given height, the mean of the range for "medium frame" was considered $100 \%$, and the criterion of obesity was an actual weight greater than $115 \%$. 
room $\left(24^{\circ} \mathrm{C}\right)$ was used instead of chromatoelectrophoretic separation in a cold room $\left(4^{\circ} \mathrm{C}\right)$. In addition strips were bisected and counted in a well-type gamma scintillation counter instead of with a strip scanner. The dose-response curve, the reproducibility of values when the same plasma samples were repeatedly assayed, and the range of values obtained in normal and diabetic patients all duplicated the performance of the original technic.

The criteria for diagnosis of diabetes mellitus were an abnormal standard oral glucose tolerance test as defined by Fajans and Conn (7), in ambulatory and otherwise healthy individuals in whom nonspecific reasons for abnormal glucose turnover had been eliminated. Normal glucose tolerance meant fasting blood glucose below $100 \mathrm{mg}$ per $100 \mathrm{ml}$, a 1 -hour value less than $160 \mathrm{mg}$ per $100 \mathrm{ml}$, and a 2-hour level below $110 \mathrm{mg}$ per $100 \mathrm{ml}$. The glucose tolerance test was diagnostic of diabetes if the 1-hour value was $160 \mathrm{mg}$ per $100 \mathrm{ml}$ or more and the 2-hour glucose level was $120 \mathrm{mg}$ per $100 \mathrm{ml}$ or higher. In the mild diabetics, fasting blood glucose was below 100 $\mathrm{mg}$ per $100 \mathrm{ml}$ in 15 patients and less than $105 \mathrm{mg}$ per $100 \mathrm{ml}$ in the other 6 ; in all individuals blood glucose exceeded $160 \mathrm{mg}$ per $100 \mathrm{ml}$ at 1 hour and was well above $120 \mathrm{mg}$ per $100 \mathrm{ml}$ at 2 hours. In the moderate diabetics, since fasting glucose was always higher than $105 \mathrm{mg}$ per $100 \mathrm{ml}$, blood levels 1 and 2 hours after the oral glucose load greatly exceeded $160 \mathrm{mg}$ per $100 \mathrm{ml}$ and 120 mg per $100 \mathrm{ml}$, respectively.

Interpretations derived from our findings (see Discussion) depend upon the validity of the following causal relationships between blood glucose concentration and insulin secretion: 1) An acute rise or fall of blood glucose level directly induces an increase or decrease, respectively, of insulin release $(1,2,8,9)$. 2) During continuous changes in circulating glucose concentrations after carbohydrate loads, the rate of insulin secretion is directly (but not necessarily linearly) proportional to the simultaneous blood glucose level.2 3) Differences between the insulin secretory responsiveness of normal versus diabetic beta cells can be semiquantitated by expressing the magnitude of insulin output per unit of glycemic stimulus, with the resulting ratio representing an empirical "index of insulinogenic reserve" (see Results and Figure 4).

In addition, the experimental design was based upon unprovable but reasonable assumptions, namely, that 1 ) in the Yalow-Berson radioimmunoassay the capacity of

${ }^{2}$ Metz (1) reported a straight-line correlation between the log of blood glucose concentration and the log of insulin secretory rate into the pancreaticoduodenal vein of dogs. Similarly, in our study the regression equation relating corresponding blood glucose and plasma insulin values on the ascending limb of the oral glucose tolerance curve in 21 nonobese normal subjects was $\log Y=$ $4.02+2.93 \log X \quad(\mathrm{r}=0.80)$. However, Colwell and Lein (10) recently showed strictly linear correlation between plasma glucose and insulin levels during the first 30 minutes after ingestion of $200 \mathrm{~g}$ glucose by normal subjects, prediabetics, and mild diabetics. endogenous insulin to react with specific antibody is synonymous with biological activity, such that actual concentrations of immunoinsulin content and biological insulin activity per milliliter of plasma are identical ; 2) the concentration of glucose in antecubital venous blood is directly proportional to the concomitant glucose level in pancreatic arterial blood; and 3) the insulin content of antecubital venous plasma directly reflects the simultaneous concentration in pancreatic venous plasma.

\section{Results}

\section{Nonobese subjects and patients}

1) Insulin secretion during intravenous glucose tolerance test (Figure 1 and Tables $I$ and $I I$ ). Normal subjects responded immediately and maximally to the massive glycemic stimulus, in contrast to progressively blunted secretory responses in the diabetic groups. At the end of the 5-minute injection into normal subjects, the rise in blood glucose from $72 \pm 1 \mathrm{mg}$ per $100 \mathrm{ml}$ (mean \pm $\mathrm{SEM}$ ) to $296 \pm 7 \mathrm{mg}$ per $100 \mathrm{ml}$ was paralleled by an increase in plasma insulin from $10 \pm 1 \mu \mathrm{U}$ per $\mathrm{ml}$ to $142 \pm 14 \mu \mathrm{U}$ per $\mathrm{ml}(\mathrm{p}<0.001)$. Thereafter, blood glucose dropped rapidly to a normal fasting level by 60 minutes, accompanied by a similar swift decline in circulating insulin concentration. Conversely, in mild diabetics the 5 -minute blood glucose level of $294 \pm 17 \mathrm{mg}$ per

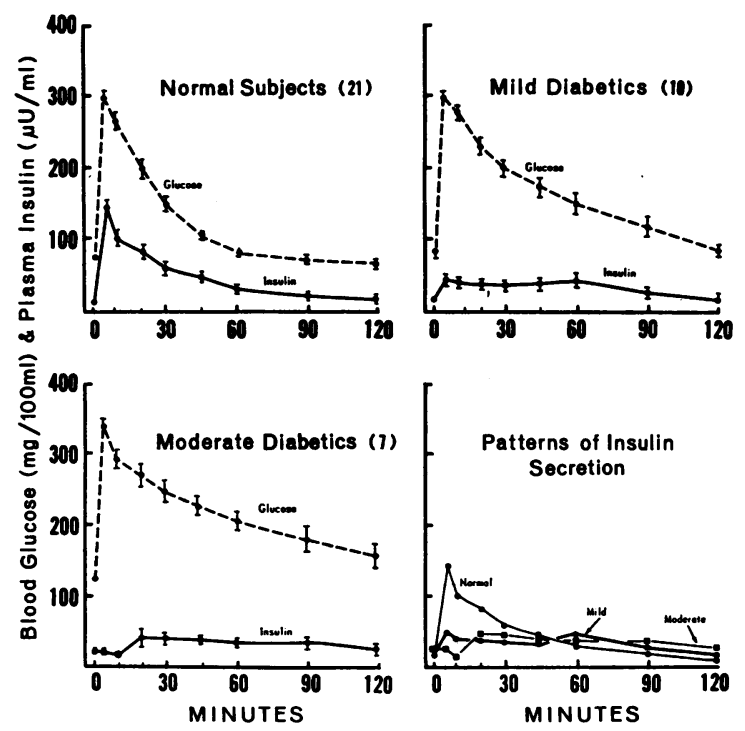

Fig. 1. INSULIN SECRETION IN NONOBESE PATIENTS AFTER INTRAVENOUS GLUCOSE LOAD. Values for blood glucose and plasma insulin are plotted as mean \pm standard error of the mean. In the lower right quadrant, mean insulin curves are superimposed for comparison. 
TABLE I

Blood glucose concentrations during intravenous glucose tolerance test

\begin{tabular}{|c|c|c|c|c|c|c|c|c|c|c|}
\hline & & \multicolumn{9}{|c|}{ Minutes } \\
\hline & & 0 & 5 & 10 & 20 & 30 & 45 & 60 & 90 & 120 \\
\hline \multirow[b]{2}{*}{$\begin{array}{l}\text { Nonobese (21) } \\
\text { Obese (11) }\end{array}$} & & \multicolumn{9}{|c|}{$\begin{array}{c}m g / 100 m l \\
\text { Normal subjects }\end{array}$} \\
\hline & $\begin{array}{l}\text { Mean } \\
\text { SEM } \\
\text { Mean } \\
\text { SEM } \\
\text { p* }\end{array}$ & $\begin{array}{l}72 \\
\pm 1 \\
77 \\
\pm 2 \\
<0.05\end{array}$ & $\begin{array}{l}296 \\
\pm 7 \\
353 \\
\pm 10 \\
<0.001\end{array}$ & $\begin{array}{l}263 \\
\pm 5 \\
320 \\
\pm 8 \\
<0.001\end{array}$ & $\begin{array}{l}191 \\
\pm 7 \\
241 \\
\pm 6 \\
<0.001\end{array}$ & $\begin{array}{l}143 \\
\pm 5 \\
188 \\
\pm 8 \\
<0.001\end{array}$ & $\begin{array}{l}101 \\
\pm 5 \\
140 \\
\pm 10 \\
<0.005\end{array}$ & $\begin{array}{c}77 \\
\pm 4 \\
106 \\
\pm 11 \\
<0.02\end{array}$ & $\begin{array}{l}63 \\
\pm 2 \\
76 \\
\pm 6 \\
<0.05\end{array}$ & $\begin{array}{r}61 \\
\pm 2 \\
64 \\
\pm 6\end{array}$ \\
\hline \multirow[t]{2}{*}{$\begin{array}{l}\text { Nonobese (10) } \\
\text { Obese (11) }\end{array}$} & $\begin{array}{l}\text { Mean } \\
\text { SEM } \\
\text { Mean } \\
\text { SEM }\end{array}$ & $\begin{array}{r}86 \\
\pm 4 \\
84 \\
\pm 3\end{array}$ & $\begin{array}{r}294 \\
\pm 17 \\
307 \\
\pm 16\end{array}$ & $\begin{array}{r}277 \\
\pm 13 \\
277 \\
\pm 13\end{array}$ & $\begin{array}{r}236 \\
\pm 9 \\
240 \\
\pm 11\end{array}$ & $\begin{array}{l}\text { Id diabeti } \\
209 \\
\pm 11 \\
213 \\
\pm 11\end{array}$ & $\begin{array}{r}\text { s } \\
181 \\
\pm 12 \\
189 \\
\pm 11\end{array}$ & $\begin{array}{r}154 \\
\pm 12 \\
167 \\
\pm 8\end{array}$ & $\begin{array}{r}118 \\
\pm 13 \\
133 \\
\pm 7\end{array}$ & $\begin{array}{r}89 \\
\pm 8 \\
105 \\
\pm 6\end{array}$ \\
\hline & & \multicolumn{9}{|c|}{ Moderate diabetics } \\
\hline $\begin{array}{l}\text { Nonobese (7) } \\
\text { Obese (7) }\end{array}$ & $\begin{array}{l}\text { Mean } \\
\text { SEM } \\
\text { Mean } \\
\text { SEM } \\
\text { p* }\end{array}$ & $\begin{array}{l}126 \\
\pm 8 \\
154 \\
\pm 8 \\
<0.05\end{array}$ & $\begin{array}{c}342 \\
\pm 17 \\
396 \\
\pm 18 \\
<0.05\end{array}$ & $\begin{array}{c}296 \\
\pm 12 \\
372 \\
\pm 10 \\
<0.001\end{array}$ & $\begin{array}{l}270 \\
\pm 15 \\
337 \\
\pm 10 \\
<0.005\end{array}$ & $\begin{array}{l}249 \\
\pm 14 \\
314 \\
\pm 10 \\
<0.005\end{array}$ & $\begin{array}{c}230 \\
\pm 14 \\
294 \\
\pm 12 \\
<0.005\end{array}$ & $\begin{array}{l}210 \\
\pm 15 \\
271 \\
\pm 10 \\
<0.01\end{array}$ & $\begin{array}{l}183 \\
\pm 17 \\
238 \\
\pm 10 \\
<0.02\end{array}$ & $\begin{array}{l}158 \\
\pm 16 \\
216 \\
\pm 10 \\
<0.01\end{array}$ \\
\hline
\end{tabular}

* Significance of the difference between obese and nonobese within the same group. Values greater than $\mathrm{p}<0.05$ are omitted.

TABLE II

Plasma insulin concentrations during intravenous glucose talerance test

\begin{tabular}{|c|c|c|c|c|c|c|c|c|c|c|}
\hline & & \multicolumn{9}{|c|}{ Minutes } \\
\hline & & 0 & 5 & 10 & 20 & 30 & 45 & 60 & 90 & 120 \\
\hline & & \multicolumn{9}{|c|}{$\stackrel{\mu U / m l}{\text { Normal subjects }}$} \\
\hline $\begin{array}{l}\text { Nonobese (21) } \\
\text { Obese (11) }\end{array}$ & $\begin{array}{l}\text { Mean } \\
\text { SEM } \\
\text { Mean } \\
\text { SEM } \\
\text { p }^{*}\end{array}$ & $\begin{array}{l}10 \\
\pm 1 \\
23 \\
\pm 4 \\
<0.005\end{array}$ & $\begin{array}{r}142 \\
\pm 14 \\
214 \\
\pm 41\end{array}$ & $\begin{array}{r}98 \\
\pm 10 \\
191 \\
\pm 50\end{array}$ & $\begin{array}{r}82 \\
\pm 10 \\
160 \\
\pm 43\end{array}$ & $\begin{array}{c}56 \\
\pm 7 \\
130 \\
\pm 29 \\
<0.02\end{array}$ & $\begin{array}{c}42 \\
\pm 6 \\
97 \\
\pm 17 \\
<0.005\end{array}$ & $\begin{array}{l}27 \\
\pm 6 \\
74 \\
\pm 8 \\
<0.001\end{array}$ & $\begin{array}{c}16 \\
\pm 4 \\
48 \\
\pm 7 \\
<0.001\end{array}$ & $\begin{array}{l}10 \\
\pm 2 \\
34 \\
\pm 5 \\
<0.001\end{array}$ \\
\hline
\end{tabular}

Nonobese (10) Mean 12

$\begin{array}{lr}\text { Mean } & 12 \\ \text { SEM } & \pm 2\end{array}$

Obese (11)

pi 12

$\begin{array}{lr}\text { Mean } & 22 \\ \text { SEM } & \pm 3\end{array}$

$\begin{array}{ll}\mathrm{p}_{\mathrm{p}}^{*} & <0.02\end{array}$

$$
\begin{aligned}
& \begin{array}{r}
45 \\
+9
\end{array} \\
& \begin{array}{l}
37 \\
\pm 7 \\
<0.001
\end{array} \\
& <0.001 \\
& \begin{array}{r}
71 \\
+10
\end{array} \\
& <0.001 \\
& <0.005 \pm 11
\end{aligned}
$$

$\quad 42$
\pm 8
$<0.005$
77
\pm 11

Mild diabetics

$\begin{array}{lllll}41 & 46 & 47 & 31 & 18\end{array}$

$\pm 5 \quad \pm 8$

$\pm 8 \quad \pm 10 \quad \pm 6$

$\begin{array}{rr}83 & 98 \\ +9 & +12\end{array}$

96
\pm 11

$82 \quad 69$

$\pm 9 \pm 12 \pm 11 \quad \pm 13 \quad \pm 9$

$<0.02$

$<0.005$

$<0.005$

$<0.005$

$<0.05$
$<0.001$

$<0.005$

Moderate diabetics

$\begin{array}{lll}\text { Nonobese (7) } & \text { Mean } & 24 \\ & \text { SEM } & \pm 5 \\ & \text { p\& } & <0.05 \\ \text { Obese (7) } & \text { Mean } & 22 \\ & \text { SEM } & \pm 8\end{array}$

24
\pm 5
$<0.05$
24
\pm 8
$<0.00$

$16 \quad 46$

$41 \quad 40$

$<0.025$

$25 \quad 53$

40
\pm 10

36

52
\pm 17

51
\pm 13

$\pm 130.02$

$\pm 9$

$34 \quad 25$

\pm 9
$<0.02$

$\pm 26$

$\begin{array}{rrr}44 & 51 & 46 \\ \pm 13 & \pm 16 & \pm 12\end{array}$

* Significance of the difference between obese and nonobese within the same group. Values greater than $\mathrm{p}<0.05$ are omitted.

† Significance of the difference between nonobese normal subjects and mild diabetics.

¥ Significance of the difference between obese normal subjects and mild diabetics.

Significance of the difference between nonobese mild and moderate diabetics.

Significance of the difference between obese mild and moderate diabetics. 
$100 \mathrm{ml}$ elicited only a modest rise of plasma insulin from a fasting value of $12 \pm 2 \mu \mathrm{U}$ per $\mathrm{ml}$ to $45 \pm$ $9 \mu \mathrm{U}$ per $\mathrm{ml}(\mathrm{p}<0.001$ compared to the 5 -minute value in normal subjects), and plasma insulin plateaued at a maximum of $47 \pm 8 \mu \mathrm{U}$ per $\mathrm{ml}$ as circulating glucose slowly receded to the normal fasting range by 120 minutes. In moderate diabetics, mean fasting glucose of $126 \pm 8 \mathrm{mg}$ per $100 \mathrm{ml}$ rose to $342 \pm 17 \mathrm{mg}$ per $100 \mathrm{ml}$ in $5 \mathrm{~min}$ utes with no increase above the fasting plasma insulin level of $24 \pm 5 \mu \mathrm{U}$ per $\mathrm{ml}$; as blood glucose subsided to $158 \pm 16 \mathrm{mg}$ per $100 \mathrm{ml}$ at $120 \mathrm{~min}$ utes, plasma insulin increased to a peak of only $46 \pm 15 \mu \mathrm{U}$ per $\mathrm{ml}$ at 20 minutes.

2) Insulin secretion during oral glucose tolerance test (Figure 2 and Tables III and IV). Compared to the normal response, initial insulin release in mild diabetics was slightly but insignificantly retarded, whereas in moderate diabetics it was virtually absent. In normal subjects, as mean blood glucose rose from the fasting value of $75 \pm 1 \mathrm{mg}$ per $100 \mathrm{ml}$ to $113 \pm 4 \mathrm{mg}$ per $100 \mathrm{ml}$ at 30 minutes, plasma insulin climbed steadily from $11 \pm 1 \mu \mathrm{U}$ per $\mathrm{ml}$ to a maximal value of $129 \pm 10 \mu \mathrm{U}$ per $\mathrm{ml}$ at 45 minutes and then subsided as circulating glucose returned to the fasting range. In mild diabetics, fasting blood glucose of $80 \pm 3 \mathrm{mg}$ per $100 \mathrm{ml}$ rose to $201 \pm 11 \mathrm{mg}$ per
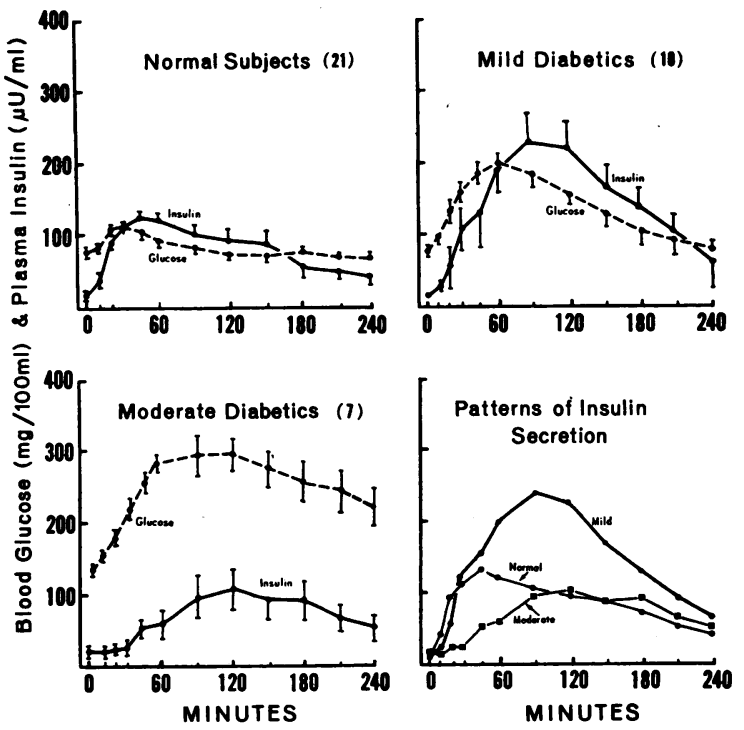

Fig. 2. INSULIN SECRETION IN NONOBESE PATIENTS AFTER ORAL GLUCOSE LOAD. Values for blood glucose and plasma insulin are plotted as mean \pm standard error of the mean. In the lower right quadrant, mean insulin curves are superimposed for comparison. Note that delayed hyperinsulinemia occurred in mild diabetics, but not in moderate diabetics.

$100 \mathrm{ml}$ in 60 minutes, then fell slowly to $155 \pm 12$ $\mathrm{mg}$ per $100 \mathrm{ml}$ at 120 minutes and to $108 \pm 14 \mathrm{mg}$ per $100 \mathrm{ml}$ at 180 minutes. Insulin release was slightly lethargic for 20 minutes, after which

TABLE III

Blood glucose concentrations during oral glucose tolerance test

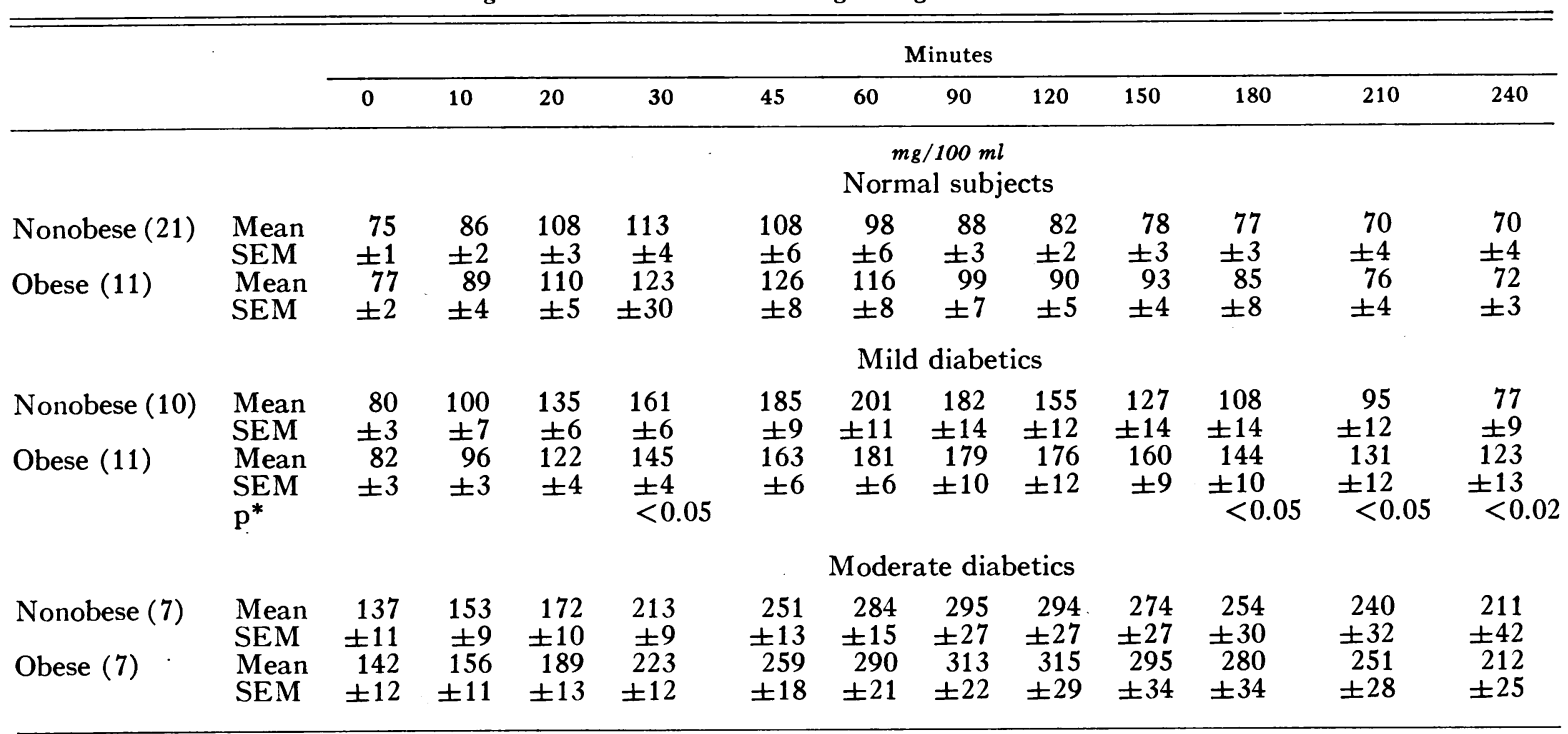

* Significance of the difference between obese and nonobese within the same group. Values greater than $\mathrm{p}<0.05$ are omitted. 
TABLE IV

Plasma insulin concentrations during oral glucose tolerance test

\begin{tabular}{|c|c|c|c|c|c|c|c|c|c|c|c|c|c|}
\hline & & \multicolumn{12}{|c|}{ Minutes } \\
\hline & & 0 & 10 & 20 & 30 & 45 & 60 & 90 & 120 & 150 & 180 & 210 & 240 \\
\hline & & & & & & & $\begin{array}{r}\mu U \\
\text { Normal }\end{array}$ & ml & & & & & \\
\hline \multirow[t]{2}{*}{ Nonobese (21) } & Mean & 11 & 40 & 93 & 111 & 129 & 122 & 103 & 93 & 89 & 70 & 52 & 44 \\
\hline & SEM & \pm 1 & \pm 7 & \pm 8 & \pm 7 & \pm 10 & \pm 11 & \pm 16 & \pm 14 & \pm 16 & \pm 15 & \pm 8 & \pm 9 \\
\hline \multirow[t]{4}{*}{ Obese (11) } & Mean & 33 & 68 & 137 & 193 & 269 & 274 & 216 & 199 & 160 & 117 & 72 & 33 \\
\hline & SEM & \pm 2 & \pm 14 & \pm 16 & \pm 18 & \pm 37 & \pm 35 & \pm 39 & $\pm \mathbf{3 7}$ & \pm 31 & \pm 23 & \pm 18 & \pm 4 \\
\hline & $\mathrm{p}^{*}$ & $<0.001$ & & $<0.02$ & $<0.001$ & $<0.001$ & $<0.001$ & $<0.02$ & $<0.02$ & $<0.05$ & & & \\
\hline & & \multicolumn{12}{|c|}{ Mild diabetics } \\
\hline \multirow[t]{2}{*}{ Nonobese (10) } & Mean & 9 & 27 & 67 & 113 & 138 & 195 & 233 & 228 & 178 & 140 & 107 & 61 \\
\hline & $\begin{array}{l}\text { SEM } \\
\text { p } \dagger\end{array}$ & \pm 2 & \pm 5 & \pm 14 & \pm 21 & \pm 36 & \pm 35 & $\begin{array}{l} \pm 42 \\
<0.01\end{array}$ & $\begin{array}{l} \pm 39 \\
<0.005\end{array}$ & $\begin{array}{l} \pm 31 \\
<0.02\end{array}$ & \pm 36 & \pm 34 & \pm 27 \\
\hline \multirow[t]{4}{*}{ Obese (11) } & Mean & 22 & 38 & 77 & 116 & 155 & 200 & 200 & 202 & 181 & 167 & 158 & 139 \\
\hline & SEM & \pm 2 & \pm 5 & \pm 8 & \pm 15 & \pm 20 & \pm 30 & \pm 16 & \pm 27 & \pm 23 & \pm 20 & \pm 19 & \pm 28 \\
\hline & pł & $<0.001$ & & $<0.005$ & $<0.005$ & $<0.02$ & & & & & & $<0.005$ & $<0.005$ \\
\hline & & \multicolumn{12}{|c|}{ Moderate diabetics } \\
\hline \multirow[t]{2}{*}{ Nonobese (7) } & Mean & 19 & 20 & 27 & 28 & 54 & 59 & 95 & 103 & 89 & 91 & 65 & 49 \\
\hline & SEM & \pm 5 & \pm 4 & \pm 11 & \pm 10 & \pm 18 & \pm 16 & \pm 25 & $\begin{array}{l} \pm 29 \\
<0025\end{array}$ & \pm 32 & \pm 28 & \pm 20 & \pm 17 \\
\hline \multirow[t]{3}{*}{ Obese (7) } & Mean & 19 & 20 & 36 & 47 & 55 & 69 & 102 & 99 & 111 & 94 & 78 & 62 \\
\hline & SEM & \pm 7 & \pm 4 & \pm 11 & \pm 13 & \pm 17 & \pm 16 & \pm 33 & $\pm \mathbf{3 0}$ & \pm 27 & \pm 27 & \pm 17 & \pm 16 \\
\hline & $\mathrm{p} \|$ & & $<0.02$ & $<0.01$ & $<0.005$ & $<0.005$ & $<0.005$ & $<0.02$ & $<0.01$ & & $<0.05$ & $<0.01$ & $<0.05$ \\
\hline
\end{tabular}

* Significance of the difference between obese and nonobese within the same group. Values greater than $\mathrm{p}<0.05$ are omitted. † Significance of the difference between nonobese normal subjects and mild diabetics. Significance of the difference between obese normal subjects and mild diabetics. Significance of the difference between nonobese mild and moderate diabetics.
Significance of the difference between obese mild and moderate diabetics.

mounting hyperglycemia evoked parallel enhancement of plasma insulin from a fasting value of $9 \pm 2 \mu \mathrm{U}$ per $\mathrm{ml}$ to a delayed peak of $233 \pm 42$ $\mu \mathrm{U}$ per $\mathrm{ml}$ at 90 minutes, and a much slower decline than in normal subjects. In the moderate diabetics, as fasting blood glucose of $137 \pm 11 \mathrm{mg}$ per $100 \mathrm{ml}$ rose to a peak value of $295 \pm 27 \mathrm{mg}$ per $100 \mathrm{ml}$ at 90 minutes and then declined to 211 $\pm 42 \mathrm{mg}$ per $100 \mathrm{ml}$ at 240 minutes, plasma insulin rose sluggishly from a control value of $19 \pm 5$ $\mu \mathrm{U}$ per $\mathrm{ml}$ to $103 \pm 29 \mu \mathrm{U}$ per $\mathrm{ml}$ at 120 minutes. The three patterns of insulin secretory response superimposed in Figure 2 again suggest that alacrity of initial insulin release tended to be inversely related to the severity of carbohydrate intolerance, but they especially emphasize that delayed hyperinsulinemia occurred only in the mildly diabetic group.

3) Relation between simultaneous plasma insulin and blood glucose concentrations. Figure 3 shows the patterns of "insulin: glucose ratios" obtained by dividing plasma insulin enhancement above fasting value by corresponding net increase of blood glucose. After both test loads, normal subjects showed a prompt, sustained rise in the insulin: glucose ratio compared to a much slower
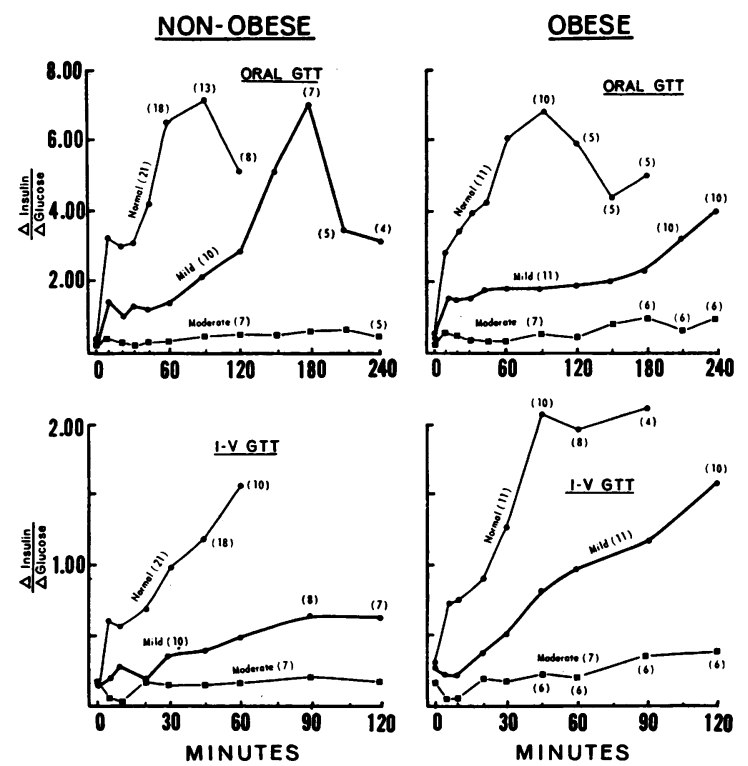

Fig. 3. Ratios Between Simultaneous increments of PLASMA INSUlin AND BLOOD GLUCOSE. The "insulinogenic index," plotted here as successive mean ratios of $\Delta$ insulin : $\Delta$ glucose at each sampling interval, shows that plasma insulin always rose relatively higher in normal subjects than in mild diabetics, regardless of body weight. Numbers in parentheses indicate the number of individuals whose glucose and insulin values were still above fasting base lines. GTT $=$ glucose tolerance test. 
rate and magnitude of increase in mild diabetics, and none at all in moderate diabetics. During the first 10 minutes after intravenous glucose, the mean ratio for normal subjects was $0.56 \pm 0.03$, and the corresponding ratio in mild diabetics was $0.22 \pm 0.06(p<0.001)$. For the initial 30 minutes after oral glucose, the mean ratio for control subjects was $3.37 \pm 0.32$, and the corresponding value for mild diabetics was $1.28 \pm 0.14(\mathrm{p}<$ $0.001)$.

4) Cumulative insulin output per unit of secretory stimulus. Figure 4 illustrates how the index of insulinogenic reserve was used to semiquantitate insulin secretory capacity, both to compare the initial hormonal output with the cumulative and "total" responses in each clinical group and to enable comparison between groups. The index was calculated by dividing the area circumscribed by the insulin curve (i.e., increment above fasting level) by the corresponding area circumscribed by the glucose curve. ${ }^{3}$ The findings in Table $\mathrm{V}$ indicate that whether blood glucose descended from an acutely imposed hyperglycemic apex, or first rose and then fell postprandially, the insulin secretory response was always much greater in normal subjects than in mild diabetics, and was even lower in moderate diabetics. Moreover, the marked differences in insulin secretory capacity were established within the first 10 minutes on the intravenous test (the index was $0.56 \pm 0.06$ for normal subjects and $0.16 \pm 0.04$ for mild diabetics $\mathrm{p}<0.001)$ and within the first 30 minutes after oral glucose (normal index was $3.07 \pm 0.34$, compared to $1.14 \pm 0.21$ in mild diabetics, $p<$ $0.001)$. For the intravenous test, the "total" insulinogenic index was $0.66 \pm 0.07(100 \%)$ for normal subjects, $0.31 \pm 0.06(47 \%)$ for mild diabetics, and $0.12 \pm 0.04(18 \%)$, for moderate diabetics. Corresponding over-all indexes after oral glucose were $4.93 \pm 0.54(100 \%), 2.43 \pm$ $0.39(49 \%)$, and $0.47 \pm 0.13(10 \%)$.

\footnotetext{
${ }^{3}$ Respective increments above fasting levels, instead of absolute values, were used for two reasons. First, blood glucose and plasma insulin levels remained constant in fasting subjects or patients lying supine for 4 hours (11). In addition, if the absolute instead of incremental glucose value had been used as divisor in calculating the ratio, diabetics with fasting hyperglycemia would have been specifically penalized without materially affecting results in normoglycemic individuals.
}

NORMAL SUBJECTS

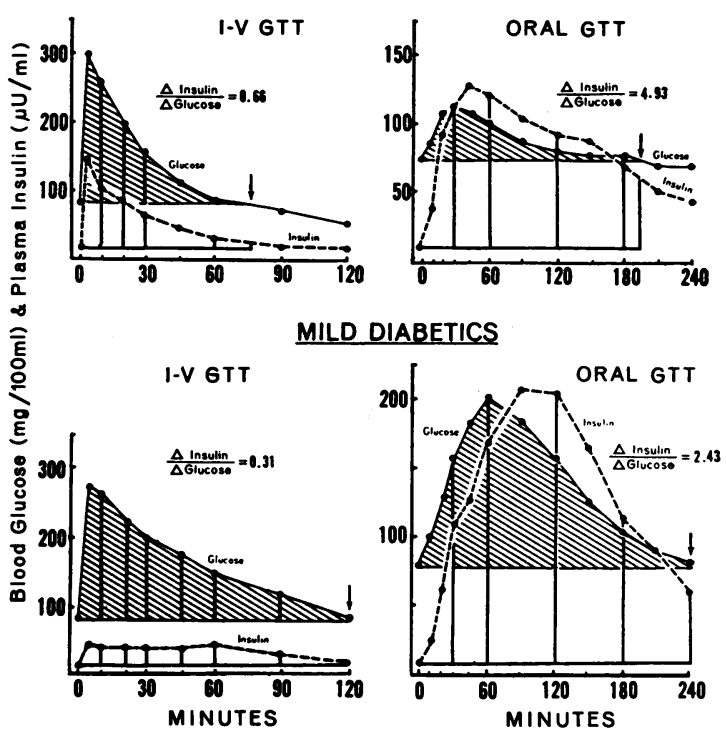

Fig. 4. INSULIN OUTPUT PER UNIT OF SECRETORY STIMuLus. The segmented shaded areas ( $\Delta$ glucose) represent cumulative enhancement of blood glucose concentration above fasting value. Arrows mark the return of blood glucose to fasting levels in normal subjects. Unshaded areas ( $\Delta$ insulin) show corresponding increases of plasma insulin above base line. Note that at progressively longer intervals on each test, normal subjects always had greater insulin output per unit glycemic stimulus than did mild diabetics (see Table V).

5) Effect of age on insulin secretory responsiveness (Figure 5). In none of the three groups did age significantly modify the insulinogenic response to intravenous or oral glucose loads. In nonobese normal subjects, circulating hormonal concentrations were the same for 13 individuals between 23 and 29 years of age (mean age 26 years) as for 8 subjects 30 to 54 years of age (average 40 years). Similarly, among mild diabetics essentially parallel patterns of hormonal release were found in 6 patients 24 to 41 years of age (mean age 35 years) and in 10 patients between 47 and 69 years (average 58 years).

\section{Obese subjects and patients}

In general, although obese nondiabetics and mild diabetics tended to produce higher plasma insulin concentrations after both glucose loads, they otherwise exhibited the same patterns of insulinogenic response as their nonobese counterparts. In addition, in obese control subjects part 
TABLE V

Index of insulinogenic reserve for cumulative intervals

\begin{tabular}{|c|c|c|c|c|c|c|c|c|c|c|}
\hline & \multicolumn{5}{|c|}{ Intervals during iv glucose tolerance test (minutes) } & \multicolumn{5}{|c|}{ Intervals during oral glucose tolerance test (minutes) } \\
\hline & $0-10$ & $0-20$ & $0-30$ & $0-60$ & Total* & $\mathbf{0 - 3 0}$ & $0-60$ & $0-120$ & $0-180$ & Total* \\
\hline Normal subjects (21) & \multicolumn{5}{|c|}{ Nonobese } & \multicolumn{5}{|c|}{ Nonobese } \\
\hline $\begin{array}{l}\text { Mean } \\
\text { SEM }\end{array}$ & $\begin{array}{r}0.56 \\
\pm 0.06\end{array}$ & $\begin{array}{r}0.56 \\
\pm 0.06\end{array}$ & $\begin{array}{r}0.59 \\
\pm 0.07\end{array}$ & $\begin{array}{r}0.65 \\
\pm 0.07\end{array}$ & $\begin{array}{r}0.66 \\
\pm 0.07\end{array}$ & $\begin{array}{r}3.07 \\
\pm 0.34\end{array}$ & $\begin{array}{r}3.76 \\
\pm 0.37\end{array}$ & $\begin{aligned} & 4.63(18) \dagger \\
\pm & 0.65\end{aligned}$ & 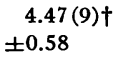 & $\begin{array}{r}4.93 \\
\pm 0.54\end{array}$ \\
\hline \multicolumn{11}{|l|}{ Mild diabetics (10) } \\
\hline $\begin{array}{l}\text { Mean } \\
\text { SEM } \\
\text { pł }\end{array}$ & $\begin{aligned} & 0.16 \\
\pm & 0.04 \\
< & 0.001\end{aligned}$ & $\begin{aligned} & 0.15 \\
\pm & 0.03 \\
< & 0.001\end{aligned}$ & $\begin{array}{c}0.17 \\
\pm 0.03 \\
<0.001\end{array}$ & $\begin{array}{c}0.24 \\
\pm 0.04 \\
<0.001\end{array}$ & $\begin{aligned} & 0.31 \\
\pm & 0.06 \\
< & 0.001\end{aligned}$ & $\begin{aligned} & 1.14 \\
\pm & 0.21 \\
< & 0.001\end{aligned}$ & $\begin{aligned} & 1.36 \\
\pm & 0.36 \\
< & 0.001\end{aligned}$ & $\begin{aligned} & 1.87 \\
\pm & 0.33 \\
< & 0.001\end{aligned}$ & $\begin{aligned} & 2.29 \\
\pm & 0.36 \\
< & 0.005\end{aligned}$ & $\begin{aligned} & 2.43 \\
\pm & 0.39 \\
< & 0.001\end{aligned}$ \\
\hline \multicolumn{11}{|l|}{ Moderate diabetics (7) } \\
\hline $\begin{array}{l}\text { Mean } \\
\text { SEM } \\
\text { p\$ }\end{array}$ & $\begin{array}{c}0.02 \\
\pm 0.01 \\
<0.005\end{array}$ & $\begin{array}{c}\quad 0.03 \\
\pm 0.01 \\
<0.005\end{array}$ & $\begin{array}{r}0.07 \\
\pm 0.02 \\
<0.01\end{array}$ & $\begin{array}{r}0.10 \\
+0.02 \\
<0.01\end{array}$ & $\begin{array}{r}0.12 \\
\pm 0.04 \\
<0.02\end{array}$ & $\begin{array}{c}0.24 \\
\pm 0.06 \\
<0.001\end{array}$ & $\begin{array}{r}0.25 \\
\pm 0.06 \\
<0.01\end{array}$ & $\begin{aligned} & 0.40 \\
\pm & 0.12 \\
< & 0.001\end{aligned}$ & $\begin{aligned} & 0.45 \\
\pm & 0.12 \\
< & 0.001\end{aligned}$ & $\begin{array}{c}0.47 \\
\pm 0.13 \\
<0.001\end{array}$ \\
\hline Normal subjects (11) & \multicolumn{5}{|c|}{ Obese } & \multicolumn{5}{|c|}{ Obese } \\
\hline $\begin{array}{l}\text { Mean } \\
\text { SEM } \\
\text { p\| }\end{array}$ & $\begin{array}{r}0.77 \\
\pm 0.15 \\
<0.25\end{array}$ & $\begin{array}{r}0.82 \\
\pm 0.19 \\
<0.25\end{array}$ & $\begin{array}{r}0.90 \\
\pm 0.22 \\
<0.25\end{array}$ & $\begin{aligned} & 1.05 \\
\pm & 0.26 \\
< & 0.2\end{aligned}$ & $\begin{aligned} & 1.12 \\
\pm & 0.25 \\
< & 0.1\end{aligned}$ & $\begin{aligned} & 3.26 \\
+ & 0.58 \\
< & 0.8\end{aligned}$ & $\begin{aligned} & 4.45 \\
& \pm 0.53 \\
&<0.4\end{aligned}$ & $\begin{aligned} & 5.40(10) \dagger \\
\pm & 0.74 \\
< & 0.5\end{aligned}$ & $\begin{aligned} & 4.80(5) \dagger \\
\pm & 1.32 \\
< & 0.9\end{aligned}$ & $\begin{aligned} & 5.45 \\
\pm & 0.69 \\
< & 0.6\end{aligned}$ \\
\hline \multicolumn{11}{|l|}{ Mild diabetics (11) } \\
\hline $\begin{array}{l}\text { Mean } \\
\text { SEM } \\
\text { pł }\end{array}$ & $\begin{aligned} & 0.25 \\
\pm & 0.05 \\
< & 0.005\end{aligned}$ & $\begin{array}{r}0.24 \\
\pm 0.05 \\
<0.01\end{array}$ & $\begin{array}{r}0.30 \\
\pm 0.05 \\
<0.02\end{array}$ & $\begin{array}{r}0.46 \\
\pm 0.06 \\
<0.05\end{array}$ & $\begin{aligned} & 0.67 \\
\pm & 0.08 \\
< & 0.1\end{aligned}$ & $\begin{array}{r}1.59 \\
\pm 0.24 \\
<0.02\end{array}$ & $\begin{aligned} & 1.76 \\
\pm & 0.24 \\
< & 0.001\end{aligned}$ & $\begin{array}{c}1.87 \\
\pm 0.22 \\
<0.001\end{array}$ & $\begin{array}{r}1.98 \\
\pm 0.20 \\
<0.05\end{array}$ & $\begin{array}{c}2.17 \\
\pm 0.21 \\
<0.001\end{array}$ \\
\hline \multicolumn{11}{|l|}{ Moderate diabetics (7) } \\
\hline $\begin{array}{l}\text { Mean } \\
\text { SEM } \\
\text { p\& }\end{array}$ & $\begin{aligned} & 0.01 \\
\pm & 0.01 \\
< & 0.001\end{aligned}$ & $\begin{aligned} & 0.02 \\
\pm & 0.01 \\
< & 0.001\end{aligned}$ & $\begin{aligned} & 0.07 \\
\pm & 0.04 \\
< & 0.005\end{aligned}$ & $\begin{aligned} & 0.15 \\
\pm & 0.05 \\
< & 0.001\end{aligned}$ & $\begin{aligned} & 0.19 \\
\pm & 0.07 \\
< & 0.001\end{aligned}$ & $\begin{aligned} & 0.37 \\
+ & 0.11 \\
< & 0.001\end{aligned}$ & $\begin{array}{c}0.33 \\
\pm 0.10 \\
<0.001\end{array}$ & $\begin{array}{c}0.44 \\
\pm 0.16 \\
<0.001\end{array}$ & $\begin{aligned} & 0.55 \\
+ & 0.22 \\
< & 0.001\end{aligned}$ & $\begin{array}{c}0.58 \\
\pm 0.23 \\
<0.001\end{array}$ \\
\hline
\end{tabular}

* Interval from $\mathbf{0}$ time until blood glucose returned to fasting level, or until end of test.

† Number of subjects whose blood glucose was still above fasting level.

Significance of the difference between normal subjects and mild diabetics.

Significance of the difference between normal subjects and mild diabetics.
Significance of the difference between mild diabetics and moderate diabetics.

Nonsignificance of the difference between obese and nonobese normal subjects.

of the excessive hormonal response after intravenous glucose was related to greater magnitude of the hyperglycemic stimulus itself.

1) Insulin secretion during intravenous glucose tolerance test (Tables $I$ and II). Both mean blood glucose and plasma insulin levels were higher during fasting and at all postinjection intervals in obese normal subjects than in nonobese normal subjects. Despite the substantially higher glucose peak at 5 minutes in obese controls (353 \pm $10 \mathrm{mg}$ per $100 \mathrm{ml}$, compared to $296 \pm 7 \mathrm{mg}$ per $100 \mathrm{ml}$ in the nonobese), respective $\mathrm{k}$ values for the disappearance rate of glucose (12) were the same, $4.62 \pm 0.28$ and $4.97 \pm 0.42$. The maximal mean plasma insulin level in obese subjects, $214 \pm$ $41 \mu \mathrm{U}$, per $\mathrm{ml}$ at 5 minutes, was not significantly higher than the corresponding value in the nonobese group, $142 \pm 14 \mu \mathrm{U}$ per $\mathrm{ml}(\mathrm{p}<0.2)$, but a statistically important difference was manifested at 30 minutes and thereafter. To equalize the glycemic stimuli, we compared the secretory responses

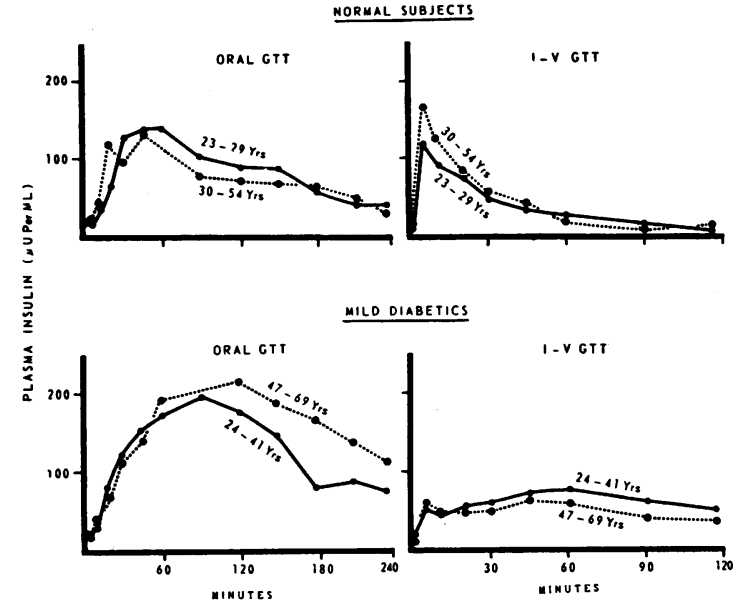

Fig. 5. EFFECT OF AGE ON INSULIN SECRETORY RESPONSIVENESS. In nonobese normal subjects mean insulin secretory curves after oral and intravenous glucose loads were essentially the same in 13 young individuals and 8 older men. Similarly, in mild diabetics respective curves of insulin release in 6 younger patients did not differ significantly from those in 10 older men. 

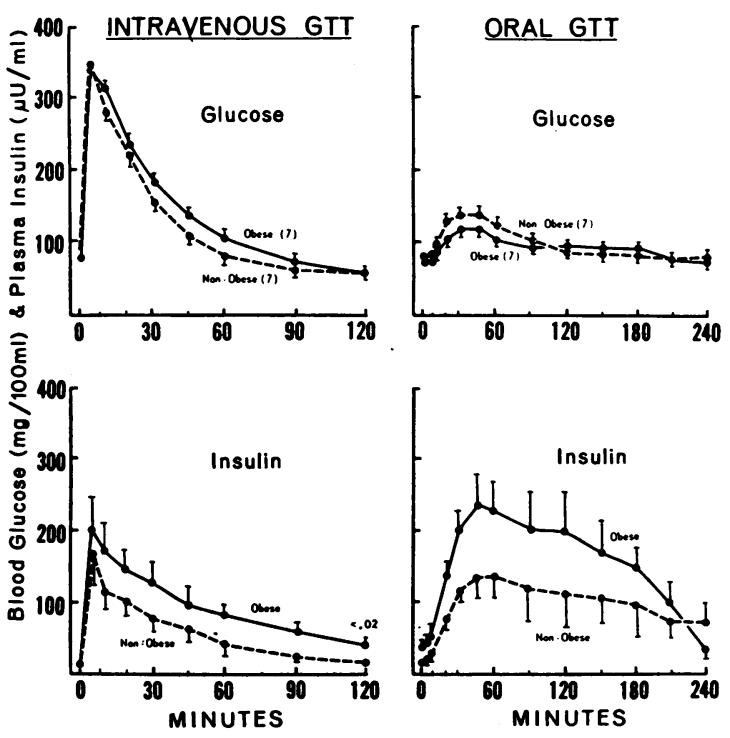

Fig. 6. SPECIFIC EFFECT OF OBESITY ON INSULIN SECRETORY RESPONSE IN NONDIABETIC SUBJECTS. By matching the 7 highest glucose curves in nonobese normal subjects with the 7 lowest ones in obese subjects after both glucose loads, we nullified the greater glycemic stimulus in the total obese group. Corresponding insulin values were then significantly higher only at 120 minutes after the intravenous load.

of 7 obese individuals with the lowest glucose curves after intravenous loading to those of the 7 nonobese control subjects with the greatest hyperglycemia (Figure 6). Mean glucose tracings were almost identical, and, although average plasma insulin levels were still higher in the obese group, the difference was only significant at 120 minutes $(\mathrm{p}<0.02)$.

Obese mild diabetics also had higher fasting and postglucose insulin levels than did mild diabetics of normal weight, but they still showed the characteristically sluggish early insulinogenic response to intense stimulus. Plasma insulin was only $71 \pm 10 \mu \mathrm{U}$ per $\mathrm{ml}$ at 5 minutes (much lower than the corresponding $214 \pm 41 \mu \mathrm{U}$ per $\mathrm{ml}$ in obese nondiabetics, $\mathrm{p}<0.005)$, whereafter it rose slowly to a maximum of $98 \pm 12 \mu \mathrm{U}$ per $\mathrm{ml}$ at 45 minutes. Compared to nonobese mild diabetics, the consistently higher mean insulin values in obese mild diabetics were not significantly greater until 20 minutes after starting glucose administration. Thus, blunted initial secretory response to acute hyperglycemia characterized the mildly diabetic state regardless of body weight, whereas prolonged maintenance of high insulin levels was a function of obesity per se in both normal subjects and mild diabetics. Finally, the obese moderately diabetic group answered an even higher glucose curve with the same lack of secretory response that nonobese moderate diabetics had manifested.

2) Insulin secretion during oral glucose tolerance test (Tables III and IV). On the whole, average oral glucose curves were insignificantly higher in all three obese groups than in their nonobese mates. Nevertheless, not only did obese normal subjects have higher fasting plasma insulin ( $33 \pm 2 \mu \mathrm{U}$ per $\mathrm{ml}$, compared to $11 \pm 1$ $\mu \mathrm{U}$ per $\mathrm{ml}$ in control subjects of normal weight, $\mathrm{p}<0.001$ ), but their circulating levels also remained significantly higher from 20 minutes until 150 minutes, the greatest difference being $274 \pm$ $35 \mu \mathrm{U}$ per $\mathrm{ml}$ at 60 minutes compared to $122 \pm 11$ $\mu \mathrm{U}$ per $\mathrm{ml}$ in nonobese subjects $(\mathrm{p}<0.001)$. When the possible influence of slightly greater average hyperglycemia in the obese group was eliminated by matching the 7 lowest glucose curves in overweight controls with the 7 highest curves in subjects of normal weight (Figure 6), the nonobese glucose curve actually became slightly higher. Nevertheless, mean plasma insulin levels remained substantially greater in obese subjects, although wide individual variations within both groups now rendered the differences insignificant at all points.

Obese mild diabetics also demonstrated the somewhat slow initial rise in plasma insulin levels that nonobese mild diabetics had shown (Table IV), and it was accentuated by comparison with the rapid and excessive outpouring of hormone in obese normal subjects. For example, although both normal weight and obese mild diabetics had virtually the same plasma insulin levels for 3 hours after the oral glucose load, from 20 minutes until 45 minutes the discrepancy between obese mild diabetics and obese normal subjects was highly significant $(\mathrm{p}<0.005)$. This latter finding contrasted with the small differences between normal weight groups during the first hour, as did also the fact that the prolonged hyperinsulinemic plateau in obese mild diabetics $(200 \pm 30 \mu \mathrm{U}$ per $\mathrm{ml}$ at 60 minutes, and still $202 \pm 27 \mu \mathrm{U}$ per $\mathrm{ml}$ at 120 minutes) never exceeded the highest level in obese normal subjects $(274 \pm 35 \mu \mathrm{U}$ per $\mathrm{ml}$ at 60 
minutes). Finally, the plasma insulin curve in obese moderate diabetics was almost identical to that of their nonobese counterparts, showing very gradual rise to a peak titer of $102 \pm 33 \mathrm{mU}$ per ml at 90 minutes.

3) Insulin: glucose ratio and the index of insulinogenic reserve. Figure 3 shows that the differences between normal and diabetic secretory responses to glycemic stimulus were as clearly evident in obese individuals as in those of normal weight. During the first 10 minutes after intravenous glucose, the mean net insulin: glucose ratio for normal obese subjects was $0.72 \pm 0.11$, and the corresponding ratio for obese mild diabetics was $0.22 \pm 0.03(p<0.001)$. After an oral glucose load, the mean ratio for the initial 30 minutes in obese controls was $3.58 \pm 0.31$, compared to $1.61 \pm 0.14(\mathrm{p}<0.001)$ in obese mild diabetics. When corresponding secretory responses were matched by calculating the insulinogenic index (Table V), both fractional and "total" values were qualitatively similar to the findings in nonobese groups. In addition, wide variations within each category kept the greater mean values in obese patients from being significantly different when matched with their normal weight counterparts. For the intravenous test the total insulinogenic index in obese individuals was $1.12 \pm$ $0.25(100 \%)$ in normal subjects, $0.67 \pm 0.08$ $(60 \%)$ in mild diabetics, and $0.19 \pm 0.07(17 \%)$ in moderate diabetics. Corresponding cumulative indexes after oral glucose were $5.45 \pm 0.69$ $(100 \%), 217 \pm 0.21(40 \%)$, and $0.58 \pm 0.23$ $(11 \%)$. The respective percentages were essentially the same as had been found in the nonobese groups.

\section{Discussion}

The present data indicate that the critical functional difference between normal and early diabetic beta cells is in the speed of response to a rising blood glucose, rather than in the total quantity of insulin secreted. In this respect diabetes mellitus remains fundamentally a disease of deficient insulin secretion, but one of rate rather than magnitude in the initial stage of the disease. When circulating insulin concentrations after glucose loading are evaluated in proper context, namely, not as isolated values but relative to the simultaneous glycemic stimuli eliciting them, it becomes clear that intact islets respond so promptly and adequately to a rising blood glucose level that postprandial hyperglycemia quickly disappears and decreases the call for further insulin secretion. Conversely, the "biochemical inertia" of the mildly diabetic beta cell permits prolonged postprandial hyperglycemia to supervene and belatedly evoke an insulinogenic response that appears at first to be excessive or supernormal. Closer scrutiny reveals, however, that the earliest detectable stage of carbohydrate intolerance in hereditary diabetes is also characterized by a second type of secretory defect, namely, proportionally less insulin is released when corrected for the magnitude of the inciting stimulus. At corresponding intervals after both oral and intravenous loads, mild diabetics always exhibited a lower insulinogenic index, i.e., less enhancement of insulin output per respective area of hyperglycemia, than did normal subjects. For example, during the oral glucose tolerance test in nonobese individuals the index (Table V) for the first 30 minutes was $3.07 \pm$ 0.34 in normal controls and $1.14 \pm 0.21$ in mild diabetics $(p<0.001)$, and respective indexes for the entire test were $4.93 \pm 0.54$ and $2.43 \pm 0.39$ $(p<0.001)$. Thus, to the extent that frequently monitored peripheral plasma insulin concentrations reflected actual insulin secretion, nondiabetics released two to three times more insulin than mild diabetics at comparable degrees of glycemic stimulus. In the group of moderate diabetics, both absolute insulin output and the index of insulinogenic capacity were even more greatly obtunded than in mild diabetics.

The findings therefore bolster interpretations deduced from previous studies $(8,13)$ which showed that insulin secretory responsiveness of diabetic patients to both acute and chronic glucose loads is inversely proportional to the clinical severity of carbohydrate intolerance, namely, that in early diabetes the initial blunting of the normal swift reaction to postalimentary rise in blood sugar seems to permit evolution of a worsening cycle of a) first, intermittent postprandial hyperglycemia, which results in $b$ ) prolonged, excessive stimulation of beta cells, which $c$ ) progressively expends insulin secretory reserve, until finally $d$ ) fasting hyperglycemia supervenes, signifying unrelenting, around-the-clock stimulation of an already damaged insulinogenic mechanism. Regarding the latter 
point, even the modest fasting hyperglycemia defining the present "moderate" diabetics was associated with obliteration of the normally rapid beta cell response to intravenous glucose, and, significantly, with absence of the delayed postprandial hyperinsulinemia seen in the "mild" diabetics, which is often accepted uncritically as a constant finding in all adult-onset diabetics.

The reported observations on insulinogenic responsiveness of intact versus diabetic beta cells held true regardless of body weight. In the 29 persons more than $15 \%$ overweight, differences among the three clinical groups were substantially similar to those in the 38 normal weight individuals. When obese versus nonobese members of the same category were compared, the only striking difference was the faster, greater, and more sustained hormonal release after both glucose loads in obese normal subjects than in control subjects of normal weight. This characteristic hyperresponsiveness of obese subjects, originally discovered by Karam and co-workers (14) in mountainous individuals averaging $95 \%$ above the norm, was also most floridly seen in our two nondiabetics who exceeded $100 \%$ of desirable weight (data not shown). Even including them, however, when individual secretory response was expressed per unit of glycemic stimulus, the much greater absolute hyperinsulinemia of obesity lost statistical meaning (Table V) because glucose tolerance of overweight subjects, albeit still normal, was sufficiently higher than in nonobese controls. When the latter presumed determinant of insulinogenesis was eliminated by matching the highest glucose curves in normal weight controls with the lowest ones in obese subjects (Figure 6), the substantial difference that persisted between mean insulin patterns on both tests was again insignificant. At the same time, the general phenomenon of greater hormonal response to glucose loads in overweight normal subjects did suggest that the obese state somehow engenders peripheral insulin resistance $(14,15)$.

When nondiabetic and diabetic groups were compared, the greater disparity between mean insulin values of obese normal subjects and obese mild diabetics during the first 45 minutes of the oral test (Table IV), relative to their nonobese analogues, was clearly due to the hyperinsulinemia of obesity being wiped out by coexistent diabetes.
Within the two diabetic groups themselves, the only remarkable feature was that plasma insulin did become significantly higher in obese mild diabetics a full 20 minutes after starting the intravenous glucose load, which finding again suggested an anti-insulin effect of obesity. In summation, however, critical scrutiny of apparent discrepancies between hormonal release in obese and nonobese counterparts revealed that the twin defects of insulin secretion in early diabetes were not related to the nutritional state of the patient. In a carefully controlled study of comparably mild diabetics, Perley and Kipnis (16) also concluded that the diabetic state is associated with reduced insulin secretory capacity, regardless of body weight.

It was gratifying that values obtained from antecubital venous blood indicated that at least the early insulinogenic response seemed directly related to glucose concentration, irrespective of pool size and other kinetics of glucose and insulin turnover. Assuming that events in the peripheral circulation of man reflect those occurring in the pancreas, many direct studies confirm the idea that the principal normal secretory stimulus is a rising level of pancreatic arterial blood glucose. Both Grodsky and co-workers (17) and Sussman, Vaughan, and Timmer (18) recently showed immediate hormonal discharge after injecting glucose into the arterial supply of the isolated pancreas. In addition, 5 minutes after starting slow administration of glucose via the femoral vein, Seltzer, Allen, and Brennan (9) found an almost threefold rise in mean pancreatic venous insulin concentration when peripheral arterial blood glucose was only $103 \pm 6 \mathrm{mg}$ per $100 \mathrm{ml}$, previous work (2) having established that glucose-induced insulinogenesis does not alter pancreatic venous blood flow.

The foregoing evidence of direct dependence of hormonal release upon glucose concentration brings into question the significance of newly postulated enteric factors as potentiators of insulin secretion. Elrick, Stimmler, Hlad, and Arai (19), McIntyre, Holdsworth, and Turner (20), Dupré (21), and Perley and Kipnis (16) all found higher insulin titers when comparable hyperglycemia was produced in man, or the same amount of glucose was given, by the oral versus intravenous route. Three of these groups suggested that 
assimilation of carbohydrate in the upper intestine stimulates release of a humoral agent that enhances the insulin-releasing potency of blood glucose level per se. Current work has narrowed the active substance down to glucagon (22), secretin (23-25), or pancreozymin (26). Whatever physiological role is ultimately ascribed te one or more gastrointestinal hormones, until someone seriously proposes that their deficiency or absence is etiologically related to diabetes mellitus, they remain irrelevant to the present analysis of the initial insulin secretory response to postprandial hyperglycemia and its consequences.

Nevertheless, the present findings did show much greater insulin release after oral glucose loads in all three clinical groups, and regardless of body weight. Different dosage schedules imposed by the experimental design, however, prevented strict comparison of the two secretory patterns for each person. Since peak blood glucose values on the intravenous test were uniformly much lower in obese subjects if dosage was calculated from desirable body weight (11), the injected amount was empirically calculated from actual body weight. On the other hand, since the oral glucose tolerance test served to separate nondiabetic control subjects from mildly diabetic patients by established testing criteria, and also to evoke a standardized "postprandial" beta cell response, the amount was necessarily based upon desirable body weight according to height. Although quantitative matching of paired insulin outputs was therefore untenable, the two secretory patterns otherwise showed a striking inferential correlation. Normal immediate hormonal release after sudden intense hyperglycemia suggested that a similarly fast response, but smaller and peripherally undetectable, was also activated by postprandially rising blood sugar, and this brisk insulinogenesis should promote avid hepatic and peripheral glucose uptake (27), which in turn would clear absorptive hyperglycemia with dispatch. Conversely, the blunted capability of mildly diabetic islets to release insulin after the same intravenous bolus of glucose implied an obtunded islet response to oral glucose as well-which relative lack of early insulin activity on hepatic and posthepatic tissues could reasonably account for the delay in metabolizing ingested glucose.

Finally, the precise nature of the lesion render- ing the diabetic islet hyporesponsive to rising blood glucose remains unknown. It may well be that this functional defect is itself not the primary lesion of hereditary diabetes, but rather the sequela of an antecedent one. In contrast to our interpretations of our findings, the majority of current opinion views delayed clearance of postprandial hyperglycemia in mild diabetes as reflecting inhibition of insulin-activated glucose transport into peripheral cells $(28,29)$. Recently proposed mechanisms underlying this antagonism include intracellular accumulation of free fatty acids (30) and intracellular deficiency of potassium (31). Suffice it to say that, if peripheral insulin resistance does contribute to increased hormonal demands in clinical diabetes, its existence need not be invoked to explain the present observations. As a compromise, one might suggest that the fundamental diabetic lesion may ultimately turn out to be generalized blockade of normal glucose transport into cells-into beta cells to catalyze release of insulin, and into peripheral cells to serve as energy substrate.

\section{Acknowledgments}

We wish to thank Miss Melba J. Loveall for technical assistance, Messrs. Walter F. Sullivan and Clyde Tilton for the medical illustrations, and Mrs. Hester R. Niswander for typing the manuscript.

\section{References}

1. Metz, R. The effect of blood glucose concentration on insulin output. Diabetes 1960, 9, 89.

2. Seltzer, H. S. Quantitative effects of glucose, sulfonylureas, salicylate, and indole-3-acetic acid on the secretion of insulin activity into pancreatic venous blood. J. clin. Invest. 1962, 41, 289.

3. Seltzer, H. S., S. S. Fajans, and J. W. Conn. Spontaneous hypoglycemia as an early manifestation of diabetes mellitus. Diabetes 1956, 5, 437.

4. Yalow, R. S., and S. A. Berson. Immunoassay of endogenous plasma insulin in man. J. clin. Invest. $1960,39,1157$.

5. MacBryde, C. M. The diagnosis of obesity. Med. Clin. N. Amer. 1964, 48, 1307.

6. Nelson, N. A. A photometric adaptation of the Somogyi method for the determination of glucose. J. biol. Chem. 1944, 153, 375.

7. Fajans, S. S. Diagnostic tests for diabetes mellitus in Diabetes, R. H. Williams, Ed. New York, Paul B Hoeber, 1960, p. 395.

8. Seltzer, H. S., and W. L. Smith. Plasma insulin activity after glucose. An index of insulogenic 
reserve in normal and diabetic man. Diabetes 1959, 8, 417.

9. Seltzer, H. S., E. W. Allen, and M. T. Brennan. Failure of prolonged sulfonylurea administration to enhance insulogenic response to glycemic stimulus. Diabetes 1965, 14, 392.

10. Colwell, J. A., and A. Lein. Diminished insulin response to hyperglycemia in prediabetes and diabetes. Diabetes 1966, 15, 519.

11. Seltzer, H. S. Unpublished observations.

12. Amatuzio, D. S., F. L. Stutzman, M. J. Vanderbilt, and $\mathrm{S}$. Nesbitt. Interpretation of the rapid intravenous glucose tolerance test in normal individuals and in mild diabetes mellitus. J. clin. Invest. 1953, 32, 428.

13. Seltzer, H. S., and V. L. Harris. Exhaustion of insulogenic reserve in maturity-onset diabetic patients during prolonged and continuous hyperglycemic stress. Diabetes 1964, 13, 6.

14. Karam, J. H., S. G. Grasso, L. C. Wegienka, G. M. Grodsky, and P. H. Forsham. Effect of selected hexoses, of epinephrine and of glucagon on insulin secretion in man. Diabetes 1966, 15, 571.

15. Rabinowitz, D., and K. L. Zierler. Forearm metabolism in obesity and its response to intraarterial insulin. Characterization of insulin resistance and evidence for adaptive hyperinsulinism. J. clin. Invest. 1962, 41, 2173.

16. Perley, M., and D. M. Kipnis. Plasma insulin responses to glucose and tolbutamide of normal weight and obese diabetic and nondiabetic subjects. Diabetes 1966, 15, 867.

17. Grodsky, G. M., A. A. Batts, L. L. Bennett, C. Vcella, N. B. McWilliams, and D. F. Smith. Effects of carbohydrates on secretion of insulin from isolated rat pancreas. Amer. J. Physiol. 1963, 205, 638.

18. Sussman, K. E., G. D. Vaughan, and R. F. Timmer. An in vitro method for studying insulin secretion in the perfused isolated rat pancreas. Metabolism 1966, 15, 466.

19. Elrick, H., L. Stimmler, C. J. Hlad, Jr., and Y. Arai. Plasma insulin response to oral and intra- venous glucose administration. J. clin. Endocr. 1964, 24, 1076.

20. McIntyre, N., C. D. Holdsworth, and D. S. Turner. Intestinal factors in the control of insulin secretion. J. clin. Endocr. 1965, 25, 1317.

21. Dupré, J. Effect of route of administration on disposal of glucose loads. J. Physiol. (Lond.) 1964, 175, 58.

22. Samols, E., G. Marri, and V. Marks. Promotion of insulin secretion by glucagon. Lancet 1965, 2, 415.

23. Dupré, J. An intestinal hormone affecting glucose disposal in man. Lancet 1964, 2, 672.

24. Unger, R. H., H. Ketterer, A. Eisentraut, and J. Dupré. Effect of secretin on insulin secretion. Lancet 1966, 2, 24.

25. Pfeiffer, E. F., M. Telib, J. Ammon, F. Melani, and $\mathrm{H}$. Ditschuneit. Letter to the editor. Diabetologia 1965, 1, 131.

26. Ketterer, H., A. Ohneda, J. Dupré, A. Eisentraut, and R. H. Unger. Effects of enteric hormones on insulin and glucagon secretion. J. Lab. clin. Med. 1966, 68, 888.

27. Madison, L. L., D. Mebane, F. Lecocq, and B. Combes. Physiological significance of the secretion of endogenous insulin into the portal circulation. V. The quantitative importance of the liver in the disposition of glucose loads. Diabetes 1963 , $12,8$.

28. Yalow, R. S., S. M. Glick, J. Roth, and S. A. Berson. Plasma insulin and growth hormone levels in obesity and diabetes. Ann. N. Y. Acad. Sci. 1965, $131,357$.

29. Schalch, D. S., and D. M. Kipnis. Abnormalities in carbohydrate tolerance associated with elevated plasma nonesterified fatty acids. J. clin. Invest. 1965, 44, 2010.

30. Schonfeld, G., and D. M. Kipnis. Studies of extracellular and tissue fatty acid pools and glucose metabolism in striated muscle. J. clin. Invest. 1966, 45, 1071.

31. Conn, J. W. Hypertension, the potassium ion and impaired carbohydrate tolerance. New Engl. J. Med. 1965, 273, 1135. 